\title{
EPILEPSIA PARTIALIS CONTINUA (KOSHEVNIKOV)
}

\author{
A PRELIMINARY CASE REPORT
}

\author{
CARLOS MAURICIO DE CASTRO-COSTA*, OTONI C. DO VALE*, \\ VICENTE LEITÃO*, CARLOS A.C. TEIXEIRA*, JOSÉ ARNALDO M. DE ARRUDA*, \\ VERALICE S. DE BRUIN*, WAGNER G. HORTA*, FRANCISCO M. B. DA CUNHA*, \\ JOSÉ ARTHUR C. D'ALMEIDA*, MARIA RISOLENE BITU ALENCAR*
}

\begin{abstract}
We report on the preliminary clinical and electrophysiological aspects of an in-patient possibly presenting epilepsia partialis continua (Koshevnikov). We discuss the different etiologies and emphasize on the possible idiopathic form in this case.
\end{abstract}

KEY WORDS: epilepsia partialis continua, electrophysiology, symptoms, idiopathic form.

\section{Epilepsia parcial contínua (Kojevnikov): relato preliminar de um caso}

RESUMO - Relatamos os aspectos clínicos e eletrofisiológicos preliminares de um paciente hospitalizado que possivelmente apresenta crises de epilepsia parcial contínua (Kojevnikov). Discutimos as diferentes etiologias dessa condição e salientamos a possível forma idiopática, nesse caso.

PALAVRAS-CHAVE: epilepsia parcial contínua, eletrofisiologia, sintomas, forma idiopática.

К о ж е в н и К о В - The different transcriptions of this name in the text and references depend on the original language in which it was written (e.g. English, German and Portuguese). In these languages, the differences are accentuated on the $j$ and $v$. In English, $j$ may be transcribed into sh, sch, and $v$ may be transcribed into $v$. In German, $j$ goes on as $j$, and $v$ may be transcribed as $w$ or ff.

Epilepsia partialis continua was firstly described by Koshevnikov ${ }^{1}$ in 1895 as a condition characterized by a continuous focal jerking of a body part, usually localized to a distal limb, and occurring over hours, days or even years. Several causes have been implicated in the genesis of this condition. This variety of etiologies is linked to variable EEG expression of this condition from normal to abnormal one as well as to a variable and refractory therapeutic response.

Epilepsia partialis continua is a rare condition, and in this paper, we aim at describing the clinical and electrophysiological characteristics of an in-patient from the University Hospital of Fortaleza (Brazil).

\section{CASE}

ARC, 19 years old, female, mullatoe, single, born in Solonópoles, Ceará State, Brazil. The patient reports that her disease began 40 days before admission to hospital with continuous rhythmic jerking movements in the

"Service of Neurology (University Hospital) / Laboratory of Experimental Neurology (Department of Physiology and Pharmacology), Federal University of Ceará, Brazil. Aceite: 1-julho-2000.

Dr. Carlos Maurício de Castro Costa - Laboratório de Neurologia Experimental e Neurofisiologia/DFF/FM/ UFC - Rua Cel. Nunes de Melo 1127 - 60430-270 Fortaleza CE - Brasil. Fax 558528788333.

E-mail:pst016@sec.secrel.com.br 
left shoulder. She reported no pain or other symptoms. Her antecedents were irrelevant for her clinical condition. The physical examination was normal. The neurological examination revealed continuous rhythmic movements in the left shoulder, absence of atrophy or fasciculations, normal tonus, force, reflexes, coordination and sensibility. Her gait was normal.

Among the exams carried out for diagnostic and etiologic investigation, the CT scan and both waking and sleep EEGs were normal. However, the study of the somatosensory evoked potentials (SSEP) showed that the amplitude of the right somatosensory evoked potential (N20 P23) was significantly higher than the left side, and that there was no significant difference in latency of the SSEP and central conduction time (N9-N20) in both sides.

The patient was treated with Clonazepam $(2 \mathrm{mg})$ twice a day, with control of the symptoms in a period of 10 months up to now. The patient has been followed up as outpatient and a complete remission of the clinical picture has been observed, so that the patient spontaneously decided to stop her medication, without recidive.

\section{DISCUSSION}

Epilepsia partialis continua is most often seen in children under 16 years, with no gender predominance ${ }^{2}$. The discharges involved in the genesis of epilepsia partialis continua seem to arise from cortical or subcortical structures ${ }^{2-7}$. It may also involve bilateral brain hemispheres with stable neurological deficit ${ }^{8}$. Clinically, it is characterized by persistent rhythmic clonic movements of one muscle group, usually of the face, arm or leg, with duration of hours, days, weeks or months, without spreading to other parts of the body. In our patient, these rhythmical movements were limited to the proximal (mostly) and distal parts of the left arm, what differs from the literature, which shows a predominance of the distal part of one extremity ${ }^{9}$.

Epilepsia partialis continua is etiologically related in children to Rassmussen encephalitis ${ }^{9,10}$, Alpers Huttenlocher disease ${ }^{11}$, Leigh syndrome and partial deficit of cytochrome c oxidase ${ }^{12}$, and neuronal migration anomalies ${ }^{13}$. In adults, it is related to vascular disease, tumor and inflammatory lesions involving the sensorimotor cortex ${ }^{9,14,15}$, non-ketotic hyperglicemia ${ }^{16}, \mathrm{HIV}^{9}$ and liver insufficiency ${ }^{17}$, and in some cases, it is of idiopathic origin.

Possibly, our patient could be included among the idiopathic group. However, the exams which were carried out in our patient are not yet sufficient to definitely show or exclude an etiology, so that further follow-up analysis, and the use of magnetic resonance imaging, for its important contribution in the diagnosis of the epilepsies, will be certainly of help to define its cause ${ }^{18,19}$.

The EEG may be normal or abnormal ${ }^{20,21}$. In our case, both waking and sleep EEGs were normal. However, SSEP were abnormal and consistent, with a decrease in local cortico-cortical inhibition and expression of hyperexcitability of motor cortex ${ }^{22}$. Moreover, the remission of myoclonies in a few months gives additional support to the hypothesis of an idiopathic form. However, further analyses of this case will possible define this etiological question.

\section{REFERENCES}

1. Kojevnikow. Eine besondere Form von corticaler Epilepsie. Neurol Centralb 1895;14:47-48.

2. Choroschko. Zur Differentialdiagnose per Polyclonia Epileptoides Continua (Kojewnikowi). Neurol Centralb 1908;27:29.

3. Omorokov L. Kojewnikoffsche Epilepsie in Sibirien. Z Ges Neurol Psychiatr 1927;107:487.

4. Kugelberg E, Widen L. Epilepsia partialis continua. Electroencephalogr Clin Neurophysiol 1954;6:503-506.

5. Juul-Jensen P, Denny-Brown D. Epilepsia partialis continua. Arch Neurol 1966;15:563-578.

6. Obeso JA, Rothwell JC, Marsden CD. The spectrum of cortical myoclonus. Brain 1985;108:193-224

7. Shorvon SD. Status epilepticus: its clinical features and treatment in children and adults. Cambridge: Cambridge Univ Press, 1994:84-97.

8. Takahashi Y, Kubota H, Fujiwara T, Yagi K, Seino M. Epilepsia partialis continua of childhood involving bilateral brain hemispheres. Acta Neurol Scand 1997;96:345-352.

9. Bartolomei F, Gavaret M, Dhiver C, et al. Isolated chronic epilepsia partialis continua in an HIV-infected patient. Arch Neurol 1999;56:111-114.

10. Andermann F. Chronic encephalitis and epilepsy. Rassmussen's Syndrome. Toronto: Butterworth-Heinemann, 1991.

11. Wrle H, Khler B, Schlote W, Winkler P, Bastanier CK. Progressive cerebral degeneration of childhood with liver disease (Alpers Huttenlocher disease) with cytochrome oxidase deficiency presenting with epilepsia partialis continua as the first clinical manifestation. Clin Neuropathol 1998;17:63-68.

12. Elia M, Musumeci SA, Ferri R, et al. Leigh syndrome and partial deficit of cytochrome c oxidase associated with epilepsia 
partialis continua. Brain Dev 1996;18:207-211

13. Fusco L, Bertini E, Vigevano F. Epilepsia partialis continua and neuronal migration anomalies. Brain Dev 1992;14:323-328.

14. Barolin GS, Scholz H, Breitfellner G, Widder W. Epilepsia partialis continua Kojevnikow: 7 Fälle. Nervenarzt 1976;47:609-613.

15. Cockerell OC, Rothwell J, Thompson PD, Marsden CD, Shorvon SD. Clinical and physiological features of epilepsia partialis continua: cases ascertained in the UK. Brain 1996;119:393-407.

16. Singh BM, Strobos RJ. Epilepsia partialis continua associated with non-ketotic hyperglycemia: clinical and biochemical profile of 21 patients. Ann Neurol 1980;8: 155-160.

17. Uterga JM, Corredera C, Barrelo G, De Miguel F. Epilepsia partialis continua: una complicación inusual de la insuficiencia hepática. Rev Esp Enferm Dig 1995;87:756-757.

18. Barkovich AJ. Malformations of neocortical development: magnetic resonance imaging correlates. Current Opin Neurol 1996;9:118-121.

19. Meiners LC. Epileptogenic lesions requiring additional MRI studies. Epilepsia 197:38(Suppl 10):19-23.

20. Watanabe K, Kuroiwa Y, Shimpo T, Shimada Y, Toyokura Y. Epilepsia partialis continua: an electrophysiological study. (Abstr). Electroencephalogr Clin Neurophysiol 1983;56:548.

21. Niedermeyer E. Epileptic seizure disorders. In Niedermeyer E, Lopes da Silva F (eds). Electroencephalography: basic principles, clinical applications, and related fields. Baltimore: Williams \& Wilkins, 1999:554-556.

22. Brown P, Ridding MC, Werhan KJ, et al. Abnormalities of the balance between inhibition and excitation in the motor cortex of patients with cortical myoclonus. Brain 1996;119:309-317. 